\title{
Shoot tips derived-somatic embryogenesis in mass propagation of Dendrobium Indonesia Raya 'Ina'
}

\author{
Fitri Rachmawati', Budi Winarto', Nurhajati Anshori Mattjik², Ni Made Armini Wiendi², Agus Purwito² \\ ${ }^{1}$ Indonesian Ornamental Crop Research Institute, Jln. Raya Ciherang, Pacet-Cianjur, West Java-Indonesia West Java-Indonesia, ${ }^{2}$ Bogor of \\ Agriculture University, Kampus IPB Darmaga, Bogor, West Java-Indonesia
}

\section{A B S T R A C T}

\begin{abstract}
A mass propagation protocol of Dendrobium Indonesia Raya 'Ina' via somatic embryogenesis pathway in producing high qualifiedseedlings was successfully established. Three different explant sources harvested from plantlets viz. shoot tips, lateral shoots and young leaves; half strength Murashige and Skoog (MS) and Vacin and Went (VW) basalt media; thidiazuron (TDZ) of 1.0, 1.5, and 2.0 mg/L; $N^{6}$-benzylaminopurine (BAP) of 0.5 and $1.0 \mathrm{mg} / \mathrm{L}$; kinetin $(\mathrm{KIN})$ of 0.5 and $1.0 \mathrm{mg} / \mathrm{L}$ were tested for embryogenic callus (EC) initiation. $\operatorname{TDZ}(0,0.1,0.3$ and $0.5 \mathrm{mg} / \mathrm{L})$ and $\operatorname{BAP}(0,0.05$ and $0.1 \mathrm{mg} / \mathrm{L})$ combination and callus densities of $1,2,3$ and $4 \mathrm{~g} / 25 \mathrm{ml}$ liquid media were studied for EC proliferation. Three, seven, ten and fourteen days period and $5 \pm 22^{\circ} \mathrm{C}, 18 \pm 2^{\circ} \mathrm{C}$, and $24 \pm 2^{\circ} \mathrm{C}$ of desiccation were investigated for conversion of EC to somatic embryo (SE) and germination of SE. The VW, haft-strength MS, Growmore (32N:10P:10K), Rosasol $^{\oplus}$, and Hyponex containing $150 \mathrm{ml} / \mathrm{L}$ coconut water $(\mathrm{CW})$ were used for plantlet preparation. Results of the studies revealed that shoot tips derived from in vitro plantlets cultured on half-strength MS semi-solid medium supplemented with $1.5 \mathrm{mg} / \mathrm{L}$ TDZ and $0.5 \mathrm{mg} / \mathrm{L}$ BAP resulted in the shortest of EC initiation time of 9.3 days after culture and $100 \%$ explant regeneration with $0.41 \mathrm{~g}$ EC fresh weight, and $4.27 \mathrm{~mm}^{3}$ volume of EC. Rapid growth and proliferation of EC was highly possible by culturing the $3 \mathrm{~g} \mathrm{EC} \mathrm{per} 25 \mathrm{ml}$ in the half strength MS liquid medium fortified by $0.50 \mathrm{mg} / \mathrm{L} \mathrm{TDZ}, 0.10 \mathrm{mg} / \mathrm{L}$ BAP, and $150 \mathrm{ml} / \mathrm{L} \mathrm{CW}$ with $11.91 \mathrm{~g}$ fresh weight of EC, $9.91 \mathrm{~g}$ EC added, and 3.97 multiplication rate. The optimal conversion of EC into SEs as high as $92.7 \%$ with 35.9 SEs per clump and $86.9 \%$ SE germination with 31.2 germinated-SEs per clump were easily determined by culturing 7 days EC desiccation at $18 \pm 2^{\circ} \mathrm{C}$ on the half strength MS medium containing $0.05 \mathrm{mg} / \mathrm{L}$ BAP with conversion time of 12.7 days for EC into SEs and 19.3 days for germination. The best performance of plantlet growth with $7.07 \mathrm{~cm}$ height of plantlets, $5.15 \mathrm{~cm}$ leaf length, 8.67 number of roots, $5.30 \mathrm{~cm}$ root length, $0.71 \mathrm{~g}$ fresh weight of plantlets, and $0.076 \mathrm{~g}$ dry weight of plantlets was significantly noticed on $2 \mathrm{~g} / \mathrm{L} \mathrm{Hyponex}^{\circ}$ medium containing $150 \mathrm{ml} / \mathrm{L} \mathrm{CW}$. The plantlets were successfully transferred to ex vitro condition on Cycas rumphii bulk with $91,6 \%$ survival rate. The established protocol is high possibly applied for other Dendrobium hybrids.
\end{abstract}

Keywords: Dendrobium Indonesia Raya 'Ina'; explants; media; embryogenic callus (EC); EC desiccation

\section{INTRODUCTION}

Dendrobium is one of important orchid commodities, widely cultivated and high market demand in Indonesia. The orchid is sold as cut flower and potted plants. The plant is sold as cut flower and potted plants with USD \$ 0.20-0.50 per stalk and USD \$3.00 - 4.00 per pot, respectively. In 2012, the orchid product reached \pm 20.714 .137 stalks per year with $\pm 1.209 .938 \mathrm{~m}^{2}$ total cultivated areas (ICBS, 2013). Export of the product can reach 34\% from total production of Indonesian orchids, especially to Japan and one of the high market demand of the Dendrobium is Dendrobium Indonesia Raya 'Ina' (DGPMAP, 2014).
$D$. Indonesia Raya 'Ina' was resulted from conventional hybridization between $D$. Kim Bora x $D$. Wee Lian and released as a new superior hybrid in 2009 under the Indonesian Center for Plant Variety Protection and Agricultural Permit. The cultivar flowers less than 2.5 year after acclimatization, has more than $80 \mathrm{~cm}$ plant height, produces four flower stalks at once with 18 - 29 flower buds per stalk, longer vase-life (more than 2.5 months), no discoloration, upright position with spiral flower, high disease resistance, and adaptability in low to medium land (The Indonesian Center for Plant Variety Protection, 2009). Although the Dendrobium has high market demand, commercialization of the variety in larger scale is constrained by availability of qualified-seedlings. 
Conventionally, the Dendrobium is propagated sexually by seeds and asexually by division of off shoots and keikies. The sexual propagation result in heterozygous seedling progenies with no warrant true-to-type plants, while the asexual one produce plants in a very limited number of 2 - 4 plants per year with a low quality and multiplication rate (Nasiruddin et al., 2003, Martin and Madassery, 2006). Therefore high promising and potential system, i.e. in vitro propagation, shall be addressed. There were several mass propagation system established previously such as via protocorm like body (plb) formation of Dendrobium hybrids (Khatun et al., 2010), dwarf Dendrobium (Sujjariturakarn and Kanchanapoom, 2011), D. aphyllum (Dutta et al., 2011), D. 'Zahra FR 62' (Winarto et al., 2013); via axillary shoot proliferation of D. nobile 'Emma White' (Asgar et al., 2011), D. longicornu (Dohling et al., 2012), D. Sonia 'Earsakul' (Kumari et al., 2013); while somatic embryogenesis studies in Dendrobium are still limited.

Several in vitro mass propagation protocols of the Dendrobium via somatic embryogenesis in producing high qualified-seedlings were successfully published previously for D. 'Chiangmai Pink' (Chung et al., 2005 and 2007), and D. 'Gradita 10' (Rachmawati et al., 2014). Chung et al. (2005) successfully found the best condition in inducing high direct embryos up to 33.6 embryos per explant of $D$. 'Chiangmai Pink' by culturing leaf explants on half-strength MS (Murashige and Skoog, 1962) medium containing $4 \mathrm{mg} / \mathrm{L}$ TDZ incubated under light for 60 days. The embryos were multiplied on the half-strength MS medium PGRs free till plantlet formation and then transferred the plantlets in ex vitro condition on sphagnum moss in $50 \%$ shaded green house. The previous study was significantly improved by applying $1 \mathrm{mg} / \mathrm{L} \alpha$-naphthalene acetic acid (NAA) and $3 \mathrm{mg} / \mathrm{L}$ thidiazuron (TDZ) for high multiplication rate up to 5.17 (Chung et al., 2007). The leaf explants of $D$. 'Gradita $10^{\prime}$ cultured on the halfstrength MS containing $1 \mathrm{mg} / \mathrm{L}$ TDZ and $0.5 \mathrm{mg} / \mathrm{L} \mathrm{N}^{6}$ benzylaminopurine (BAP) were the most suitable explant sources and medium to induce high EC up to $80 \%$ with EC initiation period as short as 26.3 days after culture. The EC was significantly proliferated on half-strength MS augmented with $0.3 \mathrm{mg} / \mathrm{L}$ TDZ and $0.1 \mathrm{mg} / \mathrm{L} \mathrm{NAA}$; converted into somatic embryos on the half-strength MS containing $0.05 \mathrm{mg} / \mathrm{L} \mathrm{BAP}$, easily germinated on the halfstrength MS fortified by $0.05 \mathrm{mg} / \mathrm{L} \mathrm{BAP}$ (Rachmawati et al., 2014). However in vitro mass propagation of $D$. Indonesia Raya 'Ina' using shoot tips as explant source via somatic embryogenesis is not reported yet.

The studies aimed to establish in vitro mass propagation protocol for $D$. Indonesia Raya 'Ina', especially to prepare qualified-seedlings continuously for commercial purposes of the variety. The researches were initiated by selecting of explant types and medium for initiation of EC, improving EC proliferation, conversing EC to SEs, germinating SEs and acclimatizing well growth-plantlets. Interestedfindings in each stage of the study are detail discussed in the paper.

\section{MATERIALS AND METHODS}

\section{Plant material and explant preparation}

Plantlets of $D$. Indonesia Raya 'Ina' ( $D$. Kim Bora x $D$. Wee Lian) (90 days old) with 3-4 leaves and 3-5 cm height used as donor explants were obtained from Edward and Frans Orchids, Prigen, Pasuruan, East Java. Explants employed in this study were shoot tips ( $\pm 0.3 \mathrm{~mm}$ in length), lateral buds ( $\pm 2 \mathrm{~mm}$ in length), and youngest leaves ( $\pm 4 \mathrm{~mm}$ in length). The explants were prepared by removing leaves gently, one by one, using a tissue culture blade under a stereo microscope. After removing all leaves, the three explants were isolated and then cultured in penicillin bottles (Ø $2.5 \mathrm{~cm} 5.5 \mathrm{~cm}$ in height) that containing $2.5 \mathrm{ml}$ of treatment media for EC induction.

\section{Effect of explant types and media on initiation of EC}

In the initiation stage of EC, two treatments were tested i.e. explant types and media. Three types of explant investigated in the experiment were shoot tips $( \pm 0.3 \mathrm{~mm}$ in length), lateral buds ( $\pm 2 \mathrm{~mm}$ in length), and youngest leaves ( $\pm 4 \mathrm{~mm}$ in length), while eight compositions of initiation media (IM) were presented in Table 1. A factorial experiment was arranged in a randomized completely block design (RCBD) with three replications. Each treatment consisted of ten bottles, each bottle contained one explants cultured on semi-solid media. The cultures were exposed to $12 \mathrm{~h}$ photoperiod under cool fluorescent lamps with $\sim 13 \mu \mathrm{mol} / \mathrm{m}^{2} / \mathrm{s}$ light intensity at $23.5 \pm 1.1^{\circ} \mathrm{C}$. The light incubation was also applied to other experiments.

All media were supplemented with $20 \mathrm{~g} / 1$ sucrose, adjusted in $\mathrm{pH} 5.8$, solidified with $2 \mathrm{~g} / \mathrm{L}$ gelrite and sterilized for $20 \mathrm{~min}$ at $121^{\circ} \mathrm{C}$ and 15 psi.

Table 1: Composition media for EC initiation of $\boldsymbol{D}$. Indonesia
Raya 'Ina'
\begin{tabular}{llccc} 
Media & Basalt media & TDZ (mg/L) & BAP (mg/L) & KIN (mg/L) \\
\hline IM-1 & Half-strength MS & 1.0 & 0.5 & - \\
IM-2 & Half-strength MS & 1.0 & 1.0 & - \\
IM-3 & Half-strength MS & 1.5 & 0.5 & - \\
IM-4 & Half-strength MS & 1.5 & 1.0 & - \\
IM-5 & VW* & 2.0 & - & 1.0 \\
IM-6 & VW & 2.0 & - & 0.5 \\
IM-7 & VW & 1.0 & - & 1.0 \\
IM-8 & VW & 1.0 & - & 0.5 \\
\hline
\end{tabular}

*VW (Vacin and Went, 1949) 
Parameters observed in this experiment were: (1) percentage of explant browning (\%), (2) time of EC initiation (day after incubation/DAI), (3) percentage of explant regeneration (\%), (4) EC fresh weight (g), and (5) EC volume $\left(\mathrm{mm}^{3}\right)$. Periodical observations were conducted to monitor alteration of explants in response to culture media till EC formation during incubation. The time for EC initiation was calculated from initial culture till EC regenerated. Percentage of explant browning and regeneration was calculated by counting number of browned-explants or regenerated-explants divided by total explants cultured times by $100 \%$ and observed 1 - 2 weeks and 4 weeks after culture. Fresh weight and volume of EC were measured one month after culture.

The EC derived from shoot tips established in the study were then proliferated by slicing the EC and culturing the pieces of EC periodically (3 times, one month each) on the half-strength MS supplemented with $1.5 \mathrm{mg} / \mathrm{L}$ TDZ, $0.5 \mathrm{mg} / \mathrm{L}$ BAP and $150 \mathrm{ml} / \mathrm{L} \mathrm{CW}$ in petridish $(5 \mathrm{~cm}$ in diameter) to prepare sufficient EC for the proliferation experiment.

\section{Effect of TDZ-BA combination and EC densities on proliferation of EC}

The half-strength MS medium containing $0.3 \mathrm{mg} / \mathrm{L}$ TDZ and $0.1 \mathrm{mg} / \mathrm{L}$ NAA was used as basic medium in the experiment. Varied combinations of the TDZ and BAP concentrations of $0,0.1,0.3$, and $0.5 \mathrm{mg} / \mathrm{L} ; 0,0.05$, and $0.1 \mathrm{mg} / \mathrm{L}$, respectively were tested in the study. All liquid media were supplemented with $150 \mathrm{ml} / \mathrm{L}$ (v/v) CW and $20 \mathrm{~g} / \mathrm{L}$ sucrose, $25 \mathrm{ml}$ of media were poured in $100 \mathrm{ml}$ erlenmeyer. EC densities investigated in the proliferation stage were 1, 2, 3, and $4 \mathrm{~g} / 25 \mathrm{ml}$ of liquid medium. All cultures were monthly subcultured periodically four times. A factorial experiment was arranged in a RCBD with three replications. Each treatment consisted of three erlenmeyers. The liquid cultures were placed on an orbital shaker on incubation racks at $80-100 \mathrm{rpm}$ under light incubation.

Parameters observed in this experiment were: (1) EC fresh weight $(\mathrm{g})$, (2) EC fresh weight added ( $\mathrm{g}$ per month), (3) multiplication rate, calculated by weighting total fresh weight of EC at the end of the culture divided by total fresh weight of EC at the initial culture, and (4) proliferation responses (percentage of EC, SEs formation and germinated-SEs; \%). The growth and development of EC or SEs during culture incubation was observed periodically. Data was recorded every month for 4 months of incubation period, but only data in the end of culture were analyzed and exhibited in text.
Effect of times and temperatures of desiccation on conversion of EC into SE and germination of SEs.

EC harvested from the previous experiment were used as explants sources, while half strength MS containing $0.05 \mathrm{mg} / \mathrm{L}$ BAP was applied as basic medium. Desiccation times applied in the experiment were $3,7,10$, and 14 days, while three desiccation temperatures were $5 \pm 2^{\circ} \mathrm{C}$, $18 \pm 2^{\circ} \mathrm{C}$, and $24 \pm 2^{\circ} \mathrm{C}$. A factorial experiment was arranged in a completely randomized design (CRD) with three replications. Each treatment consisted of three petridishes $(9 \mathrm{~cm}$ in diameter) and each petridish contained $\pm 15 \mathrm{EC}$ clumps ( $\pm 0.5 \mathrm{~cm}$ diameter).

The parameters observed in this experiment were: (1) the percentage of EC contamination (\%), (2) the percentage of EC browning (\%), (3) time of initial SEs formation (DAI), (4) percentage of SEs formation (\%), (5) number of SEs per EC clump, (6) time of initial germination of SEs (DAI), (7) percentage of SEs germination (\%), and (8) number of germinated-SEs per EC clump. Periodical observation were carried out to follow the growth and development of EC clump till germination of SEs during culture incubation. All parameters were observed and measured 2 months after incubation.

\section{Effect of media on acceleration of mini-plantlets growth}

Mini-plantlets (60 days old) with 2 - 3 leaves and $\pm 1 \mathrm{~cm}$ in heightwere used as explant sources in the study. There were 5 of acceleration media (AM) tested in the experiment i.e. (1) VW, (2) haft-strength MS, (3) $2 \mathrm{~g} / \mathrm{L}$ Growmore $^{\circledR}$ (32N:10P:10K), (4) $2 \mathrm{~g} / \mathrm{L}^{2}$ Rosasol $^{\circledR}$, and (5) $2 \mathrm{~g} / \mathrm{L}$ Hyponex $^{\circledR}$ as basal media. All media were PGRs-free and supplemented with $150 \mathrm{ml} / \mathrm{L} \mathrm{CW}, 20 \mathrm{~g} / \mathrm{L}$ of sugar, and $7 \mathrm{~g} / \mathrm{L}$ agar. The experiment was arranged in a CRD with five replications. Each treatment consisted of 5 jam bottles ( $7 \mathrm{~cm}$ in diameter). Each bottle contained 5 mini-plantlets.

The parameters observed in this experiment were: (1) height of plantlets $(\mathrm{cm}),(2)$ number of leaves per plantlet, (3) length of leaf $(\mathrm{cm})$, (4) width of leaf $(\mathrm{cm})$, (5) number of roots, (6) length of roots $(\mathrm{cm}),(7)$ fresh weight of plantlet (g), and (8) dry weight of plantlet (g). Periodical observations were carried out to follow the alteration of mini-plantlets during culture incubation. All parameters were assessed 3 months after incubation.

\section{Acclimatization of plantlets}

Well-rooted plantlets ( \pm 90 days old) with $3-5$ leaves were selected and prepared for acclimatization as described by Winarto et al. (2013). Total plantlets acclimatized were 500 plantlets, planted in five pots $(15 \mathrm{~cm}$ in diameter) and then the pots were placed in glass-house. After one week, acclimatized plantlets were watered once a day 
in the morning $(07.00-08.00 \mathrm{am})$ and fertilized twice a week with $1 \mathrm{~g} / \mathrm{L}$ of NPK (20: 20: 20). Two months after acclimatization the survival-plantlets were repotted individually in pots (15 cm in diameter) containing wood charcoal and C. rumphii bulk $(1: 1, \mathrm{v} / \mathrm{v})$. The percentage of plantlet survivability (\%) and number of survival plantlets were recorded after 2 months of acclimatization.

\section{Data analysis}

All data collected from the experiments were analyzed by analysis of variance (ANOVA) with SAS program Release Windows 6.12. All percentage data were arcsin transformed before analysis. Significant differences between means were assessed by Tukey's Studentized Range (HSD) at $P=0.05$ (Mattjik and Sumertajaya, 2006).

\section{RESULTS}

Effect of explant types and media on initiation of EC Based on periodical observation it was clearly revealed that initial EC formation was observed \pm 9 days after culture. Initial formation of EC was generally occurred after browning of explants observed (Fig. 1). The initial EC grew and increased in size 1.0 to $4.5 \mathrm{~mm}^{3}$ in diameter with varied-fresh weight values of 0.1 to $4.0 \mathrm{~g}$ EC (Fig 4A, 4B, 4C, 4D, and 4E).

Shoot tips derived from plantlets were the most suitable explants for initiation of EC with the shortest EC initiation time (11.0 days), $98.2 \%$ explant regeneration, $0.31 \mathrm{~g}$ of EC fresh weight, and $3.00 \mathrm{~mm}^{3}$ volume of EC, and $12.9 \%$ explant browning (Data not shown). Furthermore the lowest response of explants was indicated by leaf explants. The most effective medium for initiation of the EC was recorded on IM-3 semi solid medium that stimulated $87.5 \%$ growth potential of explants with $12.5 \%$ explant browning, 7.1 days of EC initiation time, $96.7 \%$ explants regeneration, $0.34 \mathrm{~g}$ of $\mathrm{EC}$ fresh weight, and $4.11 \mathrm{~mm}^{3}$ volume of EC (Data not shown). The second best medium was IM-2, while the lowest results were noticed on IM-5 medium.

The shoot tip explants and IM-3 medium were the best combination treatment with the fastest of EC initiation time of 9.3 days after culture, the highest percentage of explant regeneration up to $100 \%$ with $0.41 \mathrm{~g}$ EC fresh weight, and $4.27 \mathrm{~mm}^{3}$ volume of EC (Table 2; Fig. 1; Fig 4A, 4B, 4C, 4D and 4E). The second best combination was indicated by shoot tip explants and IM-2 medium, but leaf explants and IM-5 medium gave the lowest results in all parameters observed.

\section{Effect of TDZ-BA combination and EC densities on proliferation of EC}

In the experiment, TDZ-BA combinations and EC densities affected on the growth and proliferation of the EC. The most optimal growth and proliferation of EC were determined on PM-12 liquid medium and $3 \mathrm{~g}$ per $25 \mathrm{ml}$ EC density. The PM-12 medium and EC density of $3 \mathrm{~g}$ per $25 \mathrm{ml}$ of liquid medium were the best combination for optimal growth and proliferation of EC with $11.91 \mathrm{~g}$ EC

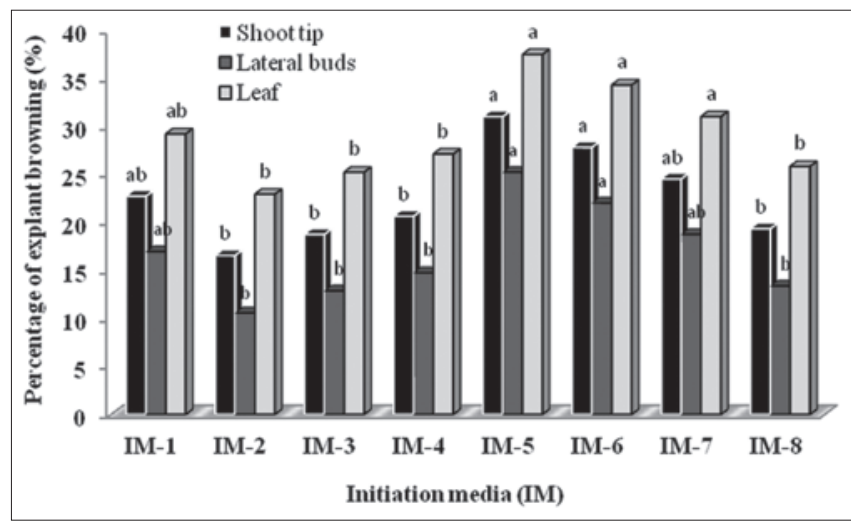

Fig 1. Interaction effect of explant types and media on percentage of explant browning (\%).

Table 2: Interaction effect of explant types and media on EC initiation of $\boldsymbol{D}$. Indonesia Raya 'Ina'

\begin{tabular}{|c|c|c|c|c|c|c|c|c|c|c|c|c|}
\hline \multirow[t]{2}{*}{$\begin{array}{l}\text { Media } \\
\text { (IM) }\end{array}$} & \multicolumn{3}{|c|}{$\begin{array}{c}\text { EC initiation times } \\
\text { (DAI) }\end{array}$} & \multicolumn{3}{|c|}{$\begin{array}{l}\text { Percentage of explant } \\
\text { regeneration }(\%)\end{array}$} & \multicolumn{3}{|c|}{$\begin{array}{l}\text { EC fresh } \\
\text { weight }(g)\end{array}$} & \multicolumn{3}{|c|}{$\begin{array}{l}\text { EC volume } \\
\left(\mathrm{mm}^{3}\right)\end{array}$} \\
\hline & $\begin{array}{l}\text { Shoot } \\
\text { tips }\end{array}$ & $\begin{array}{l}\text { Lateral } \\
\text { buds }\end{array}$ & Leaves & $\begin{array}{l}\text { Shoot } \\
\text { tips }\end{array}$ & $\begin{array}{l}\text { Lateral } \\
\text { buds }\end{array}$ & Leaves & $\begin{array}{l}\text { Shoot } \\
\text { tips }\end{array}$ & $\begin{array}{l}\text { Lateral } \\
\text { buds }\end{array}$ & Leaves & $\begin{array}{l}\text { Shoot } \\
\text { tips }\end{array}$ & $\begin{array}{l}\text { Lateral } \\
\text { buds }\end{array}$ & Leaves \\
\hline IM-1 & $11.0 \mathrm{~cd}$ & $17.0 \mathrm{ab}$ & 49.0abc & $93.3 a$ & $80.0 a b$ & $62.2 a b$ & $0.28 b c$ & $0.28 a b$ & $0.17 a b$ & 3.53ab & $2.78 b c$ & $2.11 b c$ \\
\hline IM-2 & $10.7 \mathrm{~cd}$ & $15.7 a b$ & $47.0 \mathrm{c}$ & $93.3 a$ & $87.3 a$ & $66.7 a$ & $0.31 b$ & $0.29 a b$ & $0.17 a b$ & $4.03 a$ & $3.11 b$ & $2.19 \mathrm{bc}$ \\
\hline IM-3 & $9.3 d$ & $11.7 \mathrm{c}$ & $46.7 c$ & $100.0 \mathrm{a}$ & $93.7 a$ & $66.7 a$ & $0.41 a$ & $0.32 a$ & $0.23 a$ & $4.27 a$ & $4.05 a$ & $2.88 a$ \\
\hline IM-4 & $10.0 \mathrm{~cd}$ & $15.0 \mathrm{~b}$ & $48.3 b c$ & $86.7 a b$ & $90.0 a$ & $51.1 \mathrm{c}$ & $0.30 \mathrm{~b}$ & $0.27 a b$ & $0.17 a b$ & $3.28 \mathrm{bc}$ & $2.83 \mathrm{bc}$ & $2.00 \mathrm{bc}$ \\
\hline IM-5 & $16.3 a$ & $18.3 a$ & $52.0 \mathrm{a}$ & $73.3 b$ & $76.7 \mathrm{~b}$ & $44.4 \mathrm{c}$ & $0.19 d$ & $0.20 c$ & $0.11 \mathrm{~b}$ & $2.89 c$ & $2.13 d$ & $1.44 \mathrm{e}$ \\
\hline IM-6 & $15.0 \mathrm{ab}$ & $18.0 \mathrm{ab}$ & 49.3abc & $66.7 \mathrm{bc}$ & $60.0 \mathrm{c}$ & $46.7 c$ & $0.20 \mathrm{~d}$ & $0.22 b c$ & $0.14 b$ & $3.05 c$ & $2.39 d$ & $1.53 \mathrm{de}$ \\
\hline IM-7 & $12.0 \mathrm{~cd}$ & $16.3 a b$ & $51.0 a b$ & 86.7ab & $66.7 \mathrm{bc}$ & $55.6 a b c$ & $0.22 \mathrm{~cd}$ & $0.20 c$ & $0.17 a b$ & $2.78 \mathrm{c}$ & $2.22 \mathrm{~cd}$ & $1.94 \mathrm{~cd}$ \\
\hline IM-8 & $12.3 \mathrm{~cd}$ & $15.0 \mathrm{~b}$ & $51.3 a b$ & $93.3 a$ & $86.7 a b$ & $62.2 \mathrm{ab}$ & $0.27 b c$ & $0.23 b c$ & $0.15 b$ & $3.41 \mathrm{bc}$ & $2.92 b$ & $2.03 \mathrm{bc}$ \\
\hline
\end{tabular}

Note: Average data is derived from observations of 30 explants. DAl- day after incubation. IM-1 to IM-4 used half-strength MS medium with $1 \mathrm{mg} / \mathrm{L}$ TDZ and $0.5 \mathrm{mg} / \mathrm{L} \mathrm{BA}$ (IM-1), $1 \mathrm{mg} / \mathrm{L}$ TDZ and $1 \mathrm{mg} / \mathrm{L} \mathrm{BA}$ (IM-2), $1.5 \mathrm{mg} / \mathrm{L} \mathrm{TDZ}$ and $0.5 \mathrm{mg} / \mathrm{L} \mathrm{BA}$ (IM-3), $1.5 \mathrm{mg} / \mathrm{L} \mathrm{TDZ}$ and $1 \mathrm{mg} / \mathrm{L} \mathrm{BA}$ (IM-4); IM-5 to IM-8 used VW supplemented with $1 \mathrm{mg} / \mathrm{L}$ thiamine, $2 \mathrm{mg} / \mathrm{L} \mathrm{TDZ}$ and $1 \mathrm{mg} / \mathrm{L} \mathrm{KIN} \mathrm{(IM-5),} 2 \mathrm{mg} / \mathrm{L} \mathrm{TDZ}$ and $0.5 \mathrm{mg} / \mathrm{L} \mathrm{KIN} \mathrm{(IM-6),} 1 \mathrm{mg} / \mathrm{L} \mathrm{TDZ} \mathrm{and} 1 \mathrm{mg} / \mathrm{L} \mathrm{KIN} \mathrm{(IM-7),} \mathrm{and} 1 \mathrm{mg} / \mathrm{L}$ TDZ and $0.5 \mathrm{mg} / \mathrm{L} \mathrm{KIN} \mathrm{(IM-8).} \mathrm{Means} \mathrm{followed} \mathrm{by} \mathrm{the} \mathrm{same} \mathrm{letter} \mathrm{in} \mathrm{the} \mathrm{same} \mathrm{column} \mathrm{are} \mathrm{not} \mathrm{significantly} \mathrm{different} \mathrm{based} \mathrm{on} \mathrm{Tukey} \mathrm{test} \mathrm{at} p=0.05$ 
fresh weight, 3.97 multiplication rate and $0.63 \mathrm{~g}$ EC dry weight (Table 3; Fig. 4F). Other treatments reduced the growth and proliferation of EC.

There were different proliferation responses of EC in different media. The highest percentage of EC up to $91.7 \%$ was maintained in PM-10 medium, but high conversion of EC to SEs of 32\% was occurred in PM-2 and high germination of SEs as high as $13.4 \%$ was recorded in PM-1 medium. In the study it was clearly revealed that different combination and concentration of TDZ and BAP leading to different morphogenesis responses (Table 4).

Effect of times and temperatures of desiccation on conversion of EC into SEs and germination of SEs

Times and temperatures of desiccation statistically gave significantly effect on the conversion of EC into SEs and germination of SEs. Three days and $18 \pm 2^{\circ} \mathrm{C}$ were the most suitable desiccation time and temperature for high conversion of EC into SEs and germination of SEs, however desiccation of the EC clump higher than seven days and $18 \pm 22^{\circ} \mathrm{C}$ lead to increasing explant contamination and browning (Fig. 2A and $2 \mathrm{~B}$ ) and lowering conversion results of SEs. Combination of these treatments reduced contamination and browning of explants as low as $8.3 \%$ and $10 \%$, respectively, with 12.7 days conversion time of EC into SEs, 92.7\% formation of SEs, 35.9 SEs per clump, 19.3 days germination time, $86.9 \%$ germinatedSEs, and 31.2 germinated-SEs per clump (Table 5; Fig. 3; Fig. 4G, 4H, 4I, and 4J). The second best combination results were exhibited by EC for 3 days of desiccation at $18 \pm 2^{\circ} \mathrm{C}$ and $24 \pm 2^{\circ} \mathrm{C}$, while the lowest results of EC conversion was indicated by 14 days of desiccation time at $24 \pm 2{ }^{\circ} \mathrm{C}$ with higher contamination up to $100 \%$ and $85.8 \%$ browned- explants leading to the death of explants.

Table 3: Effect of media and callus densities ( $\mathrm{g}$ per $25 \mathrm{ml}$ of liquid medium) on EC proliferation of $D$. Indonesia Raya 'Ina'

\begin{tabular}{|c|c|c|c|c|c|c|c|c|c|c|c|c|}
\hline \multirow[t]{2}{*}{$\begin{array}{l}\text { Proliferation } \\
\text { media (PM) }\end{array}$} & \multicolumn{4}{|c|}{$\begin{array}{l}\text { EC fresh } \\
\text { weight }(g)\end{array}$} & \multicolumn{4}{|c|}{$\begin{array}{l}\text { EC fresh weight added } \\
\text { (g per month) }\end{array}$} & \multicolumn{4}{|c|}{ Multiplication rate } \\
\hline & $1 \mathrm{~g}$ & $2 \mathrm{~g}$ & $3 \mathrm{~g}$ & $4 \mathrm{~g}$ & $1 \mathrm{~g}$ & $2 \mathrm{~g}$ & $3 \mathrm{~g}$ & $4 \mathrm{~g}$ & $1 \mathrm{~g}$ & $2 \mathrm{~g}$ & $3 \mathrm{~g}$ & $4 \mathrm{~g}$ \\
\hline PM -1 & $2.10 \mathrm{e}$ & $4.94 \mathrm{e}$ & $7.62 \mathrm{e}$ & $7.40 \mathrm{e}$ & $1.10 \mathrm{e}$ & $2.94 \mathrm{e}$ & 4.62ef & $3.40 \mathrm{e}$ & $2.10 \mathrm{e}$ & $2.47 f$ & $2.54 \mathrm{~g}$ & $1.85 f$ \\
\hline PM -2 & $2.18 \mathrm{e}$ & $5.10 e$ & $7.83 e$ & $7.68 \mathrm{e}$ & $1.18 \mathrm{e}$ & $3.10 \mathrm{e}$ & $4.83 e$ & $3.68 \mathrm{e}$ & $2.18 \mathrm{e}$ & $2.55 f$ & $2.61 \mathrm{~g}$ & $1.92 f$ \\
\hline PM -3 & $2.43 d$ & $5.60 d$ & $8.58 d$ & $8.68 d$ & $1.43 d$ & $3.60 \mathrm{~d}$ & $5.58 \mathrm{e}$ & $4.68 d$ & $2.43 d$ & $2.80 \mathrm{e}$ & $2.86 f$ & $2.17 \mathrm{e}$ \\
\hline PM -4 & $2.57 \mathrm{~cd}$ & $5.88 \mathrm{~cd}$ & $9.00 \mathrm{~cd}$ & $9.24 \mathrm{c}$ & $1.57 \mathrm{~cd}$ & $3.88 \mathrm{~cd}$ & $6.00 \mathrm{de}$ & $5.24 \mathrm{~cd}$ & $2.57 \mathrm{~cd}$ & $2.94 \mathrm{de}$ & $3.00 \mathrm{ef}$ & $2.31 d$ \\
\hline PM -5 & $2.62 \mathrm{c}$ & $5.98 \mathrm{~cd}$ & $9.15 \mathrm{~cd}$ & $9.44 \mathrm{c}$ & $1.62 \mathrm{~cd}$ & $3.98 \mathrm{~cd}$ & $6.15 \mathrm{de}$ & $5.44 \mathrm{c}$ & $2.62 \mathrm{~cd}$ & $2.99 \mathrm{de}$ & $3.05 e$ & $2.36 \mathrm{~d}$ \\
\hline PM -6 & $2.66 c$ & $6.06 c$ & $9.27 \mathrm{~cd}$ & $9.60 \mathrm{c}$ & $1.66 \mathrm{c}$ & $4.06 c$ & $6.27 d$ & $5.60 c$ & $2.66 c$ & $3.03 \mathrm{~cd}$ & $3.09 e$ & $2.40 d$ \\
\hline PM -7 & $2.74 \mathrm{bc}$ & $6.22 \mathrm{bc}$ & $9.54 \mathrm{c}$ & $9.96 \mathrm{bc}$ & $1.74 \mathrm{bc}$ & $4.22 \mathrm{c}$ & $6.54 d$ & $5.96 \mathrm{bc}$ & $2.74 b c$ & $3.11 \mathrm{~cd}$ & 3.18de & $2.49 \mathrm{~cd}$ \\
\hline PM -8 & $2.82 \mathrm{~b}$ & $6.38 b$ & $9.78 \mathrm{c}$ & $10.28 b$ & $1.82 \mathrm{~b}$ & $4.38 \mathrm{bc}$ & $6.78 \mathrm{~cd}$ & $6.28 \mathrm{bc}$ & $2.82 b$ & $3.19 c$ & $3.26 \mathrm{~d}$ & $2.57 c$ \\
\hline PM -9 & 3.04ab & 6.82ab & $10.74 b$ & $11.16 a$ & $2.04 a$ & 4.82ab & $7.74 c$ & $7.16 a$ & $3.04 a$ & $3.41 \mathrm{ab}$ & $3.58 \mathrm{cb}$ & 2.79ab \\
\hline PM-10 & $2.87 \mathrm{~b}$ & $6.48 b$ & $9.99 c$ & $10.44 b$ & $1.87 \mathrm{~b}$ & $4.48 b$ & $6.99 c$ & $6.44 b$ & 2.87ab & $3.24 b c$ & $3.33 d$ & $2.61 b c$ \\
\hline PM-11 & $3.08 a$ & $7.10 a$ & $11.16 a$ & $11.72 \mathrm{a}$ & $2.08 a$ & $5.10 \mathrm{a}$ & $8.16 a b$ & $7.72 a$ & $3.08 \mathrm{a}$ & $3.55 a$ & $3.72 b$ & $2.93 a$ \\
\hline PM-12 & $3.12 \mathrm{a}$ & $7.18 \mathrm{a}$ & $11.91 \mathrm{a}$ & $11.68 \mathrm{a}$ & $2.12 a$ & $5.18 a$ & $9.91 a$ & $7.68 \mathrm{a}$ & $3.12 \mathrm{a}$ & $3.59 a$ & $3.97 a$ & $2.92 a$ \\
\hline
\end{tabular}

Note: Average data is derived from observations of 9 erlenmeyers. All media used half strength MS medium supplemented with $150 \mathrm{ml} / \mathrm{L} \mathrm{CW}$. Varied combinations of the TDZ and BAP concentrations of $0,0.1,0.3$, and $0.5 \mathrm{mg} / \mathrm{L} ; 0,0.05$, and $0.1 \mathrm{mg} / \mathrm{L}$, respectively. Means followed by the same letter in the same column are not significantly different based on Tukey test at $p=0.05$

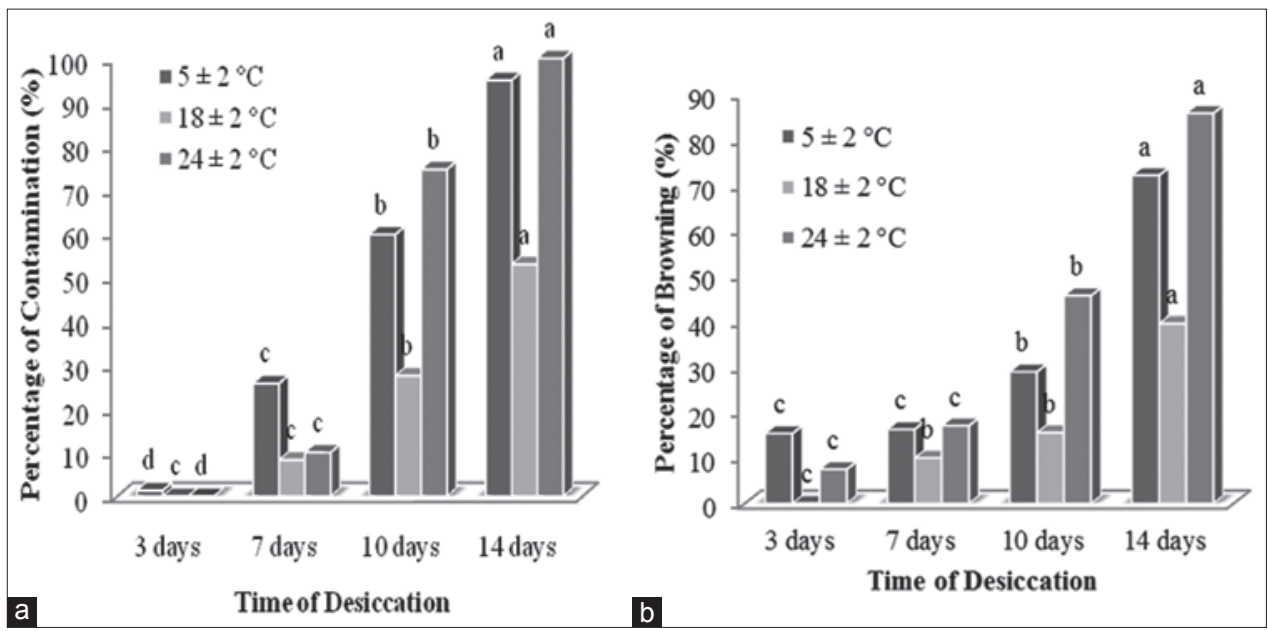

Fig 2. Effect of times and temperatures of EC desiccation on percentage of contamination (a) and explant browning (b) 
Effect of media on acceleration of mini-plantlets growth

The growth of mini-plantlets as high as $7.07 \mathrm{~cm}$ with 4.3 leaves per shoot, $5.15 \mathrm{~cm}$ length of leaf, $1.36 \mathrm{~cm}$ width of leaves, 8.67 number of roots, $5.30 \mathrm{~cm}$ length of roots, $0.71 \mathrm{~g}$ fresh weight of plantlets, and $0.076 \mathrm{~g}$ dry weight of plantlets were established on AM-5 medium (Table 6; Fig. 4K dan 4L). Other media derived from compound fertilizers Hyponex ${ }^{\circledR}$, Rosasol ${ }^{\circledR}$ or Growmore $^{\circledR}$ stimulated better growth of mini-plantlets compared to MS and VW media having analytical grade components.

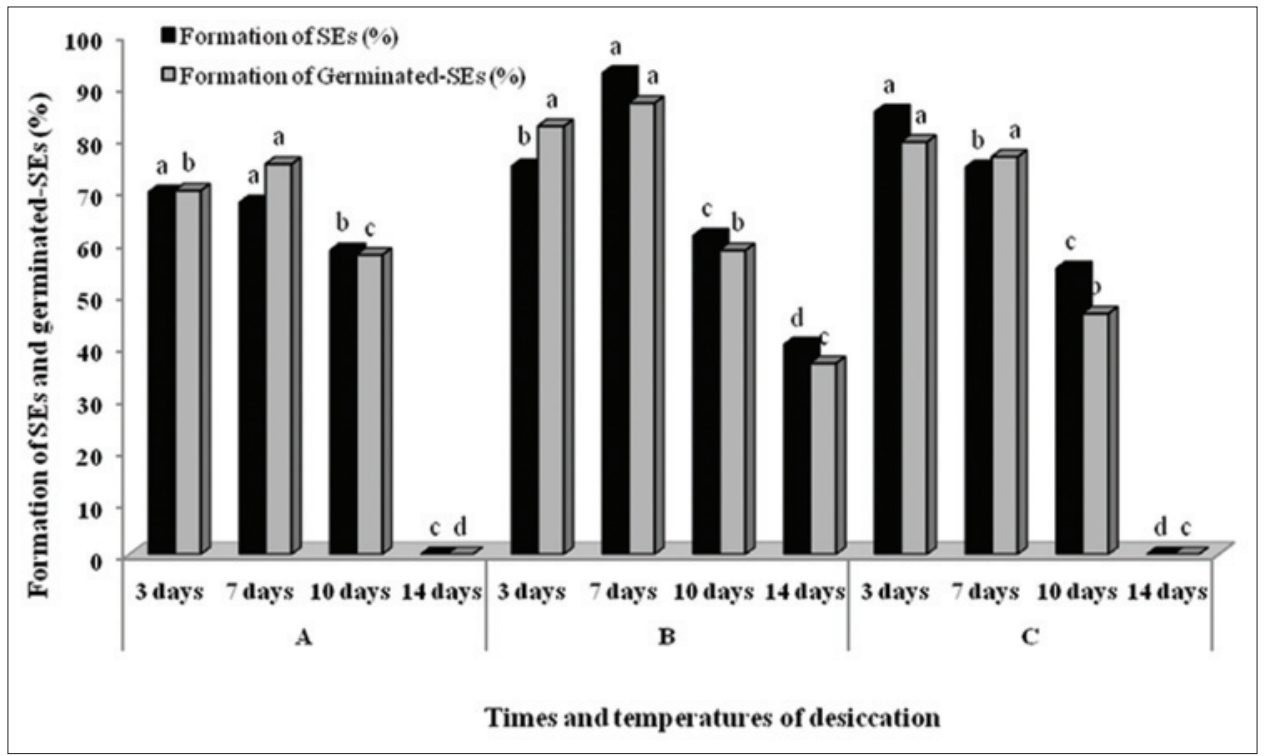

Fig 3. Effect of times and temperatures of EC desiccation on formation of SEs and germinated-SEs (\%) of D. Indonesia Raya 'Ina'. Temperatures of EC desiccation of $A\left(5 \pm 2{ }^{\circ} \mathrm{C}\right)$, $B\left(18 \pm 2{ }^{\circ} \mathrm{C}\right)$, and $\mathrm{C}\left(24 \pm 2^{\circ} \mathrm{C}\right)$.

Table 4: Proliferation responses of $\boldsymbol{D}$. Indonesia Raya 'Ina' in different media

\begin{tabular}{|c|c|c|c|c|c|}
\hline \multicolumn{3}{|c|}{ Proliferation media (PM) } & \multicolumn{3}{|c|}{ Proliferation responses } \\
\hline & $\begin{array}{c}\text { TDZ } \\
\text { (mg/L) }\end{array}$ & $\begin{array}{c}\text { BAP } \\
(\mathrm{mg} / \mathrm{L})\end{array}$ & $\begin{array}{l}\text { Percentage } \\
\text { of EC }\end{array}$ & $\begin{array}{l}\text { Percentage of } \\
\text { SEs formation }\end{array}$ & $\begin{array}{c}\text { Percentage of } \\
\text { Germinated-SEs }\end{array}$ \\
\hline PM -1 & - & - & $45.5 I$ & $31.0 \mathrm{a}$ & $13.4 \mathrm{a}$ \\
\hline PM -2 & - & 0.05 & $51.7 \mathrm{j}$ & $32.0 \mathrm{a}$ & $12.2 b$ \\
\hline PM -3 & - & 0.10 & $49.4 \mathrm{k}$ & $31.5 a$ & $11.0 \mathrm{c}$ \\
\hline PM -4 & 0.10 & - & $80.6 e$ & $8.3 f$ & $6.0 \mathrm{e}$ \\
\hline PM -5 & 0.10 & 0.05 & 61.51 & $23.0 \mathrm{~b}$ & $10.5 \mathrm{c}$ \\
\hline PM -6 & 0.10 & 0.10 & $66.0 \mathrm{~h}$ & $20.5 c$ & $9.0 d$ \\
\hline PM -7 & 0.30 & - & $89.5 b$ & $4.4 f$ & $3.0 f g$ \\
\hline PM -8 & 0.30 & 0.05 & $76.5 f$ & $13.0 \mathrm{e}$ & $6.2 \mathrm{e}$ \\
\hline PM -9 & 0.30 & 0.10 & $70.6 \mathrm{~g}$ & $18.0 d$ & $8.1 d$ \\
\hline PM-10 & 0.50 & - & $91.7 a$ & $4.0 \mathrm{~h}$ & $2.2 \mathrm{~g}$ \\
\hline PM-11 & 0.50 & 0.05 & $87.4 \mathrm{C}$ & $6.0 \mathrm{gh}$ & $3.4 f$ \\
\hline PM-12 & 0.50 & 0.10 & $84.5 d$ & $7.4 \mathrm{fg}$ & $6.0 \mathrm{e}$ \\
\hline
\end{tabular}

Note: Average data is derived from observations of 9 erlenmeyers. All media used half strength MS medium supplemented with $150 \mathrm{ml} / \mathrm{L} \mathrm{CW}$. Means followed by the same letter in the same column are not significantly different based on Tukey test at $p=0.05$

Table 5: Interaction effect of temperatures and times of desiccation on conversion of EC into SEs and germination of SEs of D. Indonesia Raya 'Ina'

\begin{tabular}{|c|c|c|c|c|c|c|c|c|c|c|c|c|}
\hline \multirow[t]{2}{*}{$\begin{array}{l}\text { Times of } \\
\text { storage }\end{array}$} & \multicolumn{3}{|c|}{$\begin{array}{c}\text { Conversion time of EC into } \\
\text { SEs }\left(\text { DAI }^{*}\right)\end{array}$} & \multicolumn{3}{|c|}{$\begin{array}{l}\text { Number of SEs } \\
\text { per clump }\end{array}$} & \multicolumn{3}{|c|}{$\begin{array}{l}\text { Germination time of } \\
\text { SEs (DAl*) }\end{array}$} & \multicolumn{3}{|c|}{$\begin{array}{l}\text { Number of germinated-SEs } \\
\text { per clump }\end{array}$} \\
\hline & $5 \pm 2^{\circ} \mathrm{C}$ & $18 \pm 2^{\circ} \mathrm{C}$ & $24 \pm 2^{\circ} \mathrm{C}$ & $5 \pm 2^{\circ} \mathrm{C}$ & $18 \pm 2^{\circ} \mathrm{C}$ & $24 \pm 2^{\circ} \mathrm{C}$ & $5 \pm 2^{\circ} \mathrm{C}$ & $18 \pm 2^{\circ} \mathrm{C}$ & $24 \pm 2^{\circ} \mathrm{C}$ & $5 \pm 2^{\circ} \mathrm{C}$ & $18 \pm 2^{\circ} \mathrm{C}$ & $24 \pm 2^{\circ} \mathrm{C}$ \\
\hline 3 days & $19.7 b$ & $14.7 c$ & $15.2 \mathrm{c}$ & $32.4 a$ & $34.1 \mathrm{a}$ & $28.6 a$ & $26.9 b$ & $21.4 \mathrm{~b}$ & $22.2 \mathrm{c}$ & $22.7 a$ & $28.1 \mathrm{a}$ & $22.7 a$ \\
\hline 7 days & $17.7 b$ & $12.7 \mathrm{c}$ & $24.5 b$ & $32.3 a$ & $35.9 a$ & $22.7 a$ & $24.3 b$ & $19.3 b$ & $31.7 b$ & $24.2 a$ & $31.2 a$ & $17.6 \mathrm{~b}$ \\
\hline 10 days & $28.5 a$ & $21.3 b$ & $35.0 a$ & $25.3 b$ & $31.3 a$ & $15.3 b$ & $35.8 a$ & $35.8 a$ & $40.6 a$ & $14.6 b$ & $18.3 b$ & $7.6 c$ \\
\hline 14 days & $0.0 c$ & $30.1 a$ & $00.0 d$ & $0.0 c$ & $26.5 b$ & $0.0 \mathrm{c}$ & $0.0 \mathrm{c}$ & $37.1 \mathrm{a}$ & $0.0 \mathrm{~d}$ & $0.0 c$ & $9.7 c$ & $0.0 \mathrm{~d}$ \\
\hline
\end{tabular}

Note: Average data is derived from observations of $30 \mathrm{EC}$ clumps. Means followed by the same letter in the same column are not significantly different based on Tukey test at $p=0.05$ 


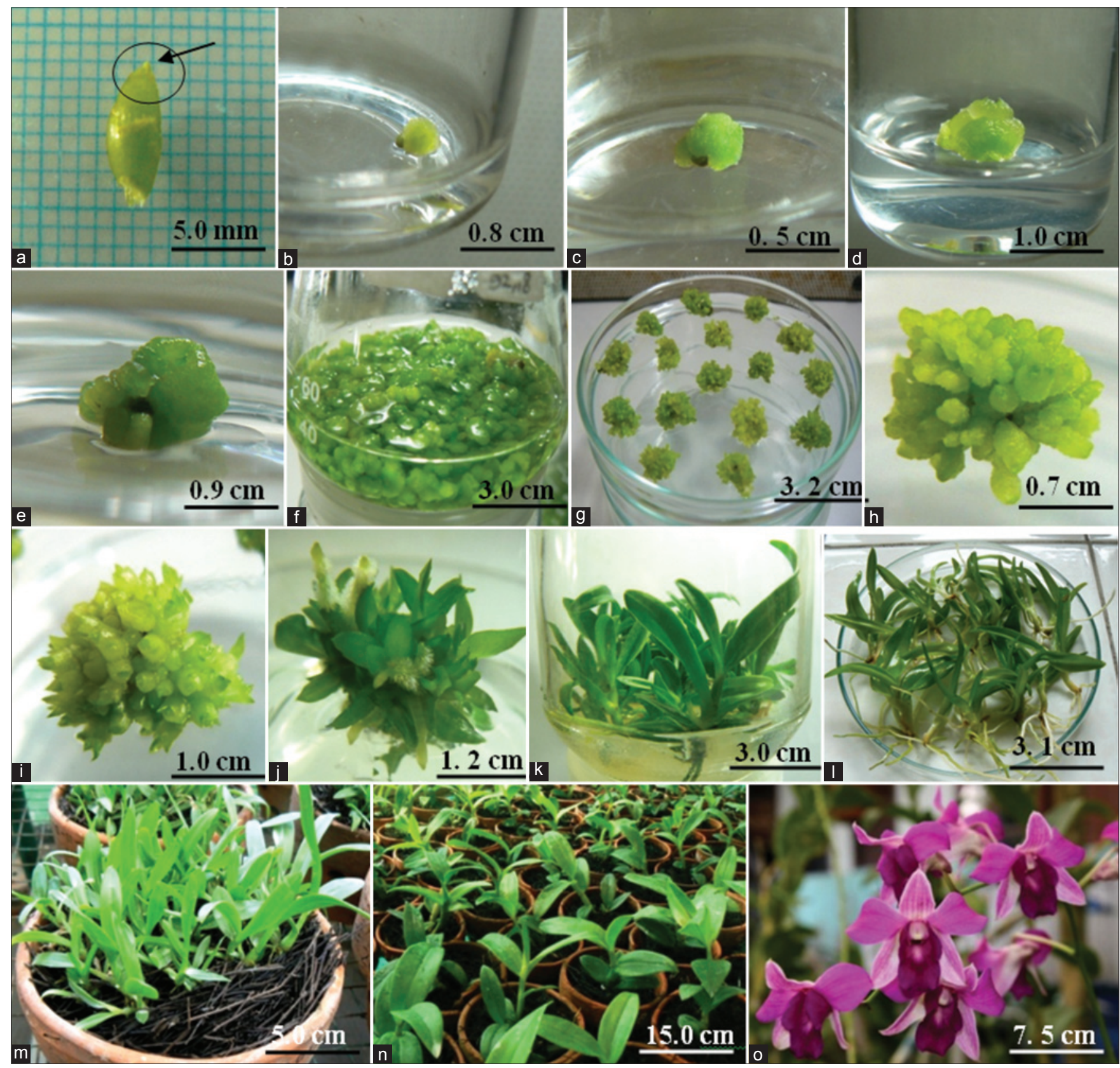

Fig 4. Mass propagation protocol of $D$. Indonesia Raya 'Ina' via somatic embryogenesis pathway. (a) Shoot tip isolated from plantlets usedas explants source. (b) Initial-EC was successfully regenerated \pm 2 weeks after culture on half strength MS containing $1.5 \mathrm{mg} / \mathrm{L}$ TDZ and $0.5 \mathrm{mg} / \mathrm{L}$ BAP. (c) The growth of regenerated-EC \pm 1 months after culture. (d) Early proliferation of $E C \pm 1.5$ months after culture. (e) Early proliferation of EC \pm 2 months after culture. (f) Proliferation of EC (5 months old) in liquid medium. (g) Conversion of EC into SE on semi solid medium. (h) Growth SEs derived from 7 days of $E C$ desiccation at $18 \pm 2^{\circ} \mathrm{C} \pm 20$ days after culture. (i) Initial germination of SEs derived from the similar desiccation \pm 1.5 months after culture. (j) Germinated SE's performance \pm 2 months after culture. (k) The growth of plantlets on AM- 5 medium \pm 3 months after culture. (I) Well rooted-plantlets harvested \pm 3 months after culture. $(\mathrm{m})$ Acclimatized-plantlets 1 month after transferring in ex vitro condition. (n) Individual plants after repotting \pm 4 months after acclimatization. (o) Well-bloomed donor plant of $D$. Indonesia Raya 'Ina' \pm 2.5 years olds.

\section{Acclimatization of plantlets}

In the acclimatization stage, 500 plantlets were successfully transferred to ex vitro condition in C. rumphii bulk with high survival rate of $91.6 \%$ (Fig. 4M). Two months after acclimatization, the survival and well growth of plantlets were repotted individually in plastic pots $15 \mathrm{~cm}$ in diameter) containing wood charcoal and C. rumphii bulk
$(1: 1, \mathrm{v} / \mathrm{v})$ for further growth. After 4 months, vigorous and healthy plants were established (Fig. 4N).

\section{DISCUSSION}

The new finding in in vitro mass propagation of $D$. Indonesia Raya 'Ina' using somatic embryogenesis pathway was 
Rachmawati, et al.: Shoot tips, embryogenesis, propagation, Dendrobium

Table 6: Effect of different media on acceleration of mini-plantlets growth $D$. Indonesia Raya 'Ina' after three month was subcultured on solid media

\begin{tabular}{|c|c|c|c|c|c|c|c|c|}
\hline $\begin{array}{l}\text { Acceleration media } \\
\text { (AM) }\end{array}$ & $\begin{array}{c}\text { Height of } \\
\text { plantlet }(\mathrm{cm})\end{array}$ & $\begin{array}{c}\text { Number of leaves } \\
\text { per plantlet }\end{array}$ & $\begin{array}{l}\text { Length of } \\
\text { leaf }(\mathrm{cm})\end{array}$ & $\begin{array}{l}\text { Width of } \\
\text { leaf }(\mathrm{cm})\end{array}$ & $\begin{array}{l}\text { Number } \\
\text { of roots }\end{array}$ & $\begin{array}{l}\text { Length of } \\
\text { roots }(\mathrm{cm})\end{array}$ & $\begin{array}{l}\text { Fresh weight } \\
\text { of plantlet }(g)\end{array}$ & $\begin{array}{c}\text { Dry weight of } \\
\text { plantlet }(\mathrm{g})\end{array}$ \\
\hline AM-1 VW & $2.23 c$ & $3.67 \mathrm{bc}$ & $1.95 c$ & $1.17 \mathrm{~b}$ & $2.00 c$ & $0.70 \mathrm{e}$ & $0.060 \mathrm{~d}$ & $0.005 d$ \\
\hline Half strength MS & $2.87 c$ & $6.00 \mathrm{a}$ & $2.55 b c$ & $1.59 a$ & $3.00 \mathrm{c}$ & $2.40 \mathrm{c}$ & $0.250 c$ & $0.010 c$ \\
\hline 2g/L growmore & $4.20 \mathrm{~b}$ & $3.33 c$ & $3.32 b$ & $1.12 b$ & $5.33 b$ & $1.77 d$ & $0.253 c$ & $0.014 c$ \\
\hline $2 \mathrm{~g} / \mathrm{L}$ rosasol & $5.03 b$ & $4.33 b$ & $3.10 \mathrm{~b}$ & $1.48 \mathrm{a}$ & $6.33 b$ & $3.63 b$ & $0.387 b$ & $0.033 b$ \\
\hline 2g/L hyponex & $7.07 a$ & $4.33 b$ & $5.15 a$ & $1.36 a b$ & $8.67 a$ & $5.30 a$ & $0.710 a$ & $0.076 a$ \\
\hline
\end{tabular}

Note: Average data is derived from observations of 25 plantlets. Means followed by the same letter in the same column are not significantly different based on Tukey test at $p=0.05$

successfully developed (Fig. 4). The protocol that was initiated from selection of explants and media, followed by proliferation till acclimatization has almost similar protocol established previously for $D$. 'Gradita 10' with slightly alteration, especially for selected medium for EC proliferation (Rachmawati et al., 2014).

The shoot tips cultured on the half-strength MS semisolid medium supplemented with $1.5 \mathrm{mg} / \mathrm{L}$ TDZ and $0.5 \mathrm{mg} / \mathrm{L}$ BAP was the best explant and medium to induce EC initiation time as short as 9.3 days with $100 \%$ explant regeneration; while in D. 'Gradita 10' $80 \%$ of EC formation in 23.6 days after culture was derived from leaf explants cultured on the same basal medium fortified by $1.0 \mathrm{mg} / \mathrm{L}$ TDZ and $0.5 \mathrm{mg} / \mathrm{L}$ BAP (Rachmawati et al., 2014). Roy and Banerjee (2003) successfully stimulated high EC formation up to $66.7 \%$ after 2 weeks of culture derived from shoottip explants of $D$. fimbriatum Lindl. var aculatum Hk. f. cultured on modified Knudson $\mathrm{C}$ medium (Knudson, 1946) containing $0.5 \mathrm{mg} / \mathrm{L} \mathrm{NAA}, 1 \mathrm{mg} / \mathrm{L}$ BAP, $10 \%$ (v/v) CW, $0.5 \mathrm{mg} / \mathrm{L}$ niacin, $0.5 \mathrm{mg} / \mathrm{L}$ pyridoxine $\mathrm{HCl}$, $0.1 \mathrm{mg} / \mathrm{L}$ thiamin $\mathrm{HCl}$. In D. chrysotoxum, the $69 \%$ callus formation regenerated from the similar explants was significantly proved by applying $0.44 \mathrm{mg} / \mathrm{L}$ TDZ or BAP in the Knudson C basal medium (Roy et al., 2007), $68 \%$ the EC formation derived from PLBs slicing for $D$. 'Sonia 28' for six weeks after culture was on the halfstrength MS medium augmented with $1 \mathrm{mg} / \mathrm{L} \mathrm{NAA}$ and $0.1 \mathrm{mg} / \mathrm{L} \mathrm{2,4-D}$ and $2 \mathrm{mg} / \mathrm{L}$ tryptone (Mei et al., 2012), 100\% EC formation for less than 20 days after culture for $D$. sabin was on MS medium supplemented with 5\% of sucrose (Rafique et al., 2012). All reported studies were clearly revealed that high EC formation was significantly affected by the suitability of explant selected and initiation medium established.

Varied-EC proliferation media with their modifications have unique and specific effect on proliferation of the $\mathrm{EC}$ in different Dendrobium in vitro cultures. Density of $3 \mathrm{~g} \mathrm{EC}$ per $25 \mathrm{ml}$ and half strength MS liquid medium fortified by $0.50 \mathrm{mg} / \mathrm{L}$ TDZ, $0.10 \mathrm{mg} / \mathrm{L} \mathrm{BAP}$, and $150 \mathrm{ml} / \mathrm{L} \mathrm{CW}$ was the best treatment for EC proliferation. In the $D$.
'Gradita 10', high proliferation of EC was proved with 2 - $3 \mathrm{~g}$ of EC cultured in $25 \mathrm{ml}$ the half-strength MS liquid medium containing $0.3 \mathrm{mg} / \mathrm{L}$ TDZ and $0.1 \mathrm{mg} / \mathrm{L}$ NAA (Rachmawati et al., 2014). In other studies, rapid proliferation of EC was established by subculturing EC in selected initiation medium determined previously as reported on $D$. 'Sonia 17' and 'Sonia 18' using halfstrength MS medium containing $10 \mathrm{mg} / \mathrm{L}$ BA (Martin and Madassery, 2006); increasing concentration of TDZ and NAA in half-strength MS medium from 0 to $3 \mathrm{mg} / \mathrm{L}$ and 0 to $1 \mathrm{mg} / \mathrm{L}$, respectively, for $D$. 'Chiangmai Pink' (Chung et al., 2007) and applying Rosasol ${ }^{\circledR}$ medium (1.5 g/L 25N: 10P:10K + TE + $1.5 \mathrm{~g} / \mathrm{L} 15 \mathrm{~N}: 10 \mathrm{P}: 30 \mathrm{~K}+\mathrm{TE}$ ) containing $150 \mathrm{ml} / \mathrm{L} \mathrm{CW}$ for $D$. 'Jayakarta', $D$. 'Gradita 31' and $D$. 'Zahra FR 62' (Winarto, 2012).

Application of TDZ and BAP individually and/or in combination in the study giving high significant effect on morphogenesis responses of $\mathrm{EC}$ was successfully revealed. Application of TDZ in higher concentration (more than $0.3 \mathrm{mg} / \mathrm{L}$ ) and combination of TDZ-BAP in higher concentration significantly maintained $\mathrm{EC}$ in the similar condition more than $80 \%$, while removing TDZ and applying TDZ-BAP in lower concentration induced SEs formation and SEs germination up to $32 \%$ and $13 \%$, respectively. Utilization of TDZ and BAP combination to maintain EC condition and SE formation was also recorded in the previous study for $D$. 'Jayakarta', $D$. 'Gradita 31' and D. 'Zahra FR 62' (Winarto, 2012), D. 'Gradita 10' (Rachmawati et al., 2014), D. Gradita 31' (Winarto and Rachmawati, 2013), D. 'Zahra FR 62' (Winarto et al., 2013).

The desiccation of EC and/or SEs in varied-ways would reduce water content; reserve accumulated carbohydrates, lipids and proteins; increase stability of SEs; harden SEs and accelerate maturation of SEs leading to high SEs germination rate with high quality performances (Etienne et al., 2006; Srinivas et al., 2006). Under the treatment alteration of the pattern of gene expression from a maturation program to germination, breaking dormancy and post-germination growth was occurred (Gray, 1989). Furthermore combination of 7 days and $18 \pm 2^{\circ} \mathrm{C} \mathrm{EC}$ desiccation successfully induced the highest conversion of 
EC into SEs and SEs germination (Tabel 5). In different study, 5 days EC starvation at room temperature and culturing on half-strength MS resulted in 20-fold increase in SEs production, enhanced maturation and germination of Daucus carota SEs (Lee et al., 2001), $48 \mathrm{~h}$ desiccation in combination with chilling leading to $58.3 \%$ SEs formation of Citrus jambbiri (Singh, 2014), exposing embryos to $2.6 \mathrm{mg} / \mathrm{L}$ abscisic acid (ABA) followed by $2 \mathrm{~h}$ desiccation at $10{ }^{\circ} \mathrm{C}$ increased SEs germination up to $56 \%$ in Musa spp cv. Rasthali (AAB) (Srinivas et al., 2006).

Contamination and browning of explants in desiccation step that are important problem in in vitro culture of orchids were also recorded in the study with $0-100 \%$ and $0-86 \%$, respectively. The high contamination occurred due to desiccation process during exposing EC in limited-air free in sterile petridishes at $24 \pm 2{ }^{\circ} \mathrm{C}$ more than 7 days. Longer exposing EC, higher contamination and browning explants occurred with $100 \%$ and $86 \%$ of them recorded at 14 days of desiccation mostly due to bacteria. The higher contamination up to $24 \%$ was also reported in in vitro Phalaenopsis (Lesar et al., 2012) and $26 \%$ on Pleurothallis glumacea (Alvarez-Pardo, 2006). Furthermore browning explants are occurred due to accumulation of phenolic compounds causing the loss of growth capacity and tissue death during culture (Rittirat et al., 2012). In the study the browning explants were presumably induced by light surface damage of EC during active shaking in liquid medium and exposing to air-free during desiccation.

Accelerating growth of mini-plantlets, sometime, was needed to prepare best performance of plantlets readily for acclimatization. In the study, well growth of plantlets was significantly established by culturing mini-plantlets on $2 \mathrm{~g} / \mathrm{L}$ Hyponex ${ }^{\mathbb{B}}$ medium containing $150 \mathrm{ml} / \mathrm{L} \mathrm{CW}$. In other studies, the vigorous and healthy plantlets were established by culturing germinated-SEs and/or PLBs on half-strength MS medium fortified by $2 \mathrm{~g} / \mathrm{L}$ activated charcoal for $D$. 'Sonia 17' and 'Sonia 18' (Martin and Madassery, 2006), MS medium with $2.0 \mathrm{mg} / \mathrm{L}$ neodymium nitrate for $D$. densiflorum (Luo et al., 2008), half-strength MS full vitamin PGRs-free for D. 'Zahra FR 62' (Winarto et al., 2013), Growmore ${ }^{\circledR}$ medium (200 mg/L 32N: 10P: 10K + $50 \mathrm{mg} / \mathrm{L} 20 \mathrm{~N}$ : 20P: $20 \mathrm{~K}+100 \mathrm{mg} / \mathrm{L}$ 6N: 30P: 30K) augmented with $100 \mathrm{ml} / \mathrm{L}$ CW (Winarto and Rachmawati, 2013).

In the most cases, high survival rate (SR) of plantlets over transferring them to ex vitro condition was easily established for Dendrobium plantlets. The high SR of 100\% in C. rumphii bulk were recorded for $D$. 'Gradita 31' (Winarto and Rachmawati, 2013), 100\% was established on a mixture of wood charcoal and C. rumphii bulk (1:2, v/v) for D. "Zahra FR 62', (Winarto et al., 2013), 95\% SR of D. nobile with peat moss, wood charcoal and bricks (1:1:1) (Nayak et al., 2002),
$92 \%$ SR in the same orchid with charcoal chips, coconut husk and broken tiles (2:2:1), 95\% SR for D. candidum with vermiculite (Zhao et al., 2008), $80 \%$ SR for $D$. 'Sonia' in a mixture of sand, brick or tile and charcoal pieces and coir fiber (1:4:4:2) (Martin and Madassery, 2006), 80-100\% SR for $D$.'Serdang Beauty' with charcoal (Khosravi et al.,2008). In the study, SR up to $91.6 \%$ was successfully established.

\section{CONCLUSIONS}

From the studies, it can be summarized that in vitro mass propagation protocol via somatic embryogenesis derived from shoot tips of plantlets for $D$. Indonesia Raya 'Ina' was successfully determined. High EC formation was established by culturing shoot tips on half-strength MS semi-solid medium supplemented with $1.5 \mathrm{mg} / \mathrm{L}$ TDZ and $0.5 \mathrm{mg} / \mathrm{L}$ BAP. The EC was easily proliferated by culturing $3 \mathrm{~g}$ EC per $25 \mathrm{ml}$ in half-strength MS liquid medium fortified by $0.50 \mathrm{mg} / \mathrm{L} \mathrm{TDZ}, 0.10 \mathrm{mg} / \mathrm{L} \mathrm{BAP}$, and $150 \mathrm{ml} / \mathrm{L} \mathrm{CW}$. Culturing of EC after 7 days of desiccation at $18 \pm 2^{\circ} \mathrm{C}$ on half-strength MS containing $0.05 \mathrm{mg} / \mathrm{L}$ BAP significantly induced the highest conversion of EC into SEs and SEs germination. The best performance of plantlet growth was noted on $2 \mathrm{~g} / \mathrm{L}$ Hyponex ${ }^{\circledR}$ medium containing $150 \mathrm{ml} / \mathrm{L} \mathrm{CW}$. The plantlets were successfully acclimatized on C. rumphii bulk with $91.6 \%$ SR.

\section{ACKNOWLEDGMENT}

We thank to the Indonesian Agency for Agriculture Research and Development for funding this research under 2013-2014 research budget.

\section{Author contributions}

F.R. contributed to research planning and all intermittent steps until manuscript preparation and revisions. B.W. was involved in research planning, carrying out experiments and collecting data. A.P.; N.M.A.W.; N.H.M. and B.W. were involved with advice regarding data analysis, experimental design, and manuscript writing and editing. All five authors approved the manuscript for publication, take public responsibility for the content, and declare no conflicts of interest associated with any aspect of this manuscript (financial or other).

\section{REFERENCES}

Alvarez-Pardo, V. M., A. G. Ferreira and V. F. Nunes. 2006. Seed disinfestation methods for in vitro cultivation of epiphyte orchids from Southern Brazil. Hortic. Bras. 24: 217-220.

Asghar, S., T. Ahmad, I. A. Hafiz and M. Yaseen. 2011. In vitro propagation of orchid (Dendrobium nobile) var. Emma white. Afr. J. Biotechnol. 10(16): 3097-3103. 
Chung, H. H., J. T. Chen and W. C. Chang. 2005. Cytokinins induce direct somatic embryogenesis of Dendrobium 'Chiangmai Pink' and subsequent plant regeneration. In Vitro Cell Dev. Biol. Plant. 41: 765-769.

Chung, H. H., J. T. Chen and W. C. Chang. 2007. Plant regeneration through direct somatic embryogenesis from leaf explants of Dendrobium. Biol. Plant. 51(2): 346-350.

Directorate General of Processing and Marketing of Agricultural Products (DGPMAP). 2011. Road Map of Orchid Post Harvesting and Trading 2011-2015. Indonesian Agriculture Ministry, Jakarta, Indonesia.

Dohling, S., S. Kumaria and P. Tandon. 2012. Multiple shoot induction from axillary bud cultures of the medicinal orchid Dendrobium longicornu. AOB Plants. 2012: 032.

Dutta, S., A. Chowdhury, B. Bhattacharjee, P. K. Nath and B. K. Dutta. 2011. In vitro multiplication and protocorm development of Dendrobium aphyllum (Roxb.) CEC Fisher. Biol. Environ. Sci. $7(1): 57-62$.

Etienne, H., E. Dechamp, D. B. Etienne and B. Bertrand. 2006. Bioreactors in coffee micropropagation. Braz. J. Plant Physiol. 18: $45-54$.

Gray, D. J. 1989. Effects of dehydration and exogenous growth regulators on dormancy. Quiescence and germination of grape somatic embryos. In Vitro Cell Dev. Biol. Plant. 25: 1173-1178.

Indonesian Center Bureau for Statistic (ICBS). 2013. Cultivation areas, production and productivity of orchids, 2009-2012. Available from: http://www.bps.co.id.>. [Last accessed 2013 Jan 31].

Khatun, H., M. M. Khatun, M. S. Biswas, M. R. Kabir and M. Al-Amin. 2010. In vitro growth and development of Dendrobium hybrids orchid. Bangladesh J. Agril. Res. 35(3): 507-514.

Khosravi, A. R., M. A. Kadir, S. B. Kazemin, F. Q. Zaman and A. E. de Silva. 2008. Establishment of a plant regeneration system from callus of Dendrobium cv. Serdang Beauty. Afr. J. Biotechnol. 7(22): 4093-4099.

Knudson, K. 1946. A new nutrient solution for germination of orchid seeds. Am. Orchids Soc. Bull. 15: 214-217.

Kumari, P., I. Sabina, T. George and K. Rajmohan. 2013. Influence of plant growth regulators on in vitro clonal propagation of Dendrobium Sonia 'Earsakul'. J. Biol. Innov. 2(2): 51-58.

Lee, E. K., D. Y. Cho and W. Y. Soh. 2001. Enhanced production and germination of somatic embryos temporary starvation in tissue culture of Daucus carota. Plant Cell Rep. 20: 408-415.

Lesar, H., N. Čeranič, D. Kastelec and Z. Luthar. 2012. Asymbiotic seed germination of Phalenopsis Blume orchids after hand pollination. Acta Agric. Slov. 99(1): 5-11.

Luo, J. P., Y. Wang, X. Q. Zha and L. Huang. 2008. Micropropagation of Dendrobium densiflorum Lindl. ex Wall. Through protocormlike bodies: Effects of plant growth regulators and lanthanoids. Plant Cell Tissue Organ Cult. 93: 333-340.

Mattjik, A. A. and I. S. Sumertajaya. 2006. Experimental Design with SAS and Minitab Application. IPB Press, Bogor, p. 276.

Martin, K. P. and J. Madassery. 2006. Rapid in vitro propagation of Dendrobium hybrids through direct shoot formation from foliar explants, and protocorm-like bodies. Sci. Hort. 108: 95-99.

Mei, T. A., M. Danial, M. Mahmood and S. Subramaniam. 2012. Exquisite protocol of callus induction and protocorm-like bodies (PLBs) regeneration of Dendrobium Sonia-28. Aust. J. Crop Sci. 6(5): 793-800.

Murashige, T. and F. Skoog. 1962. A revised medium for rapid growth and bioassay with tobacco tissue cultures. Physiol. Plant. 15: 473-497.
Nasiruddin, K. M., R. Begum and S. Yasmin. 2003. Protocorm-like bodies and plantlet regeneration from Dendrobium formosum leaf callus. Asian J. Plant Sci. 2(13): 955-957.

Nayak, N. R., S. Sahoo, S. Patnaik and S. P. Rath. 2002. Establishment of thin cross section (TCS) culture method for rapid micropropagation of Cymbidium aloifolium (L.) Sw. and Dendrobium nobile Lindl. (Orchidaceae). Sci. Hortic. 94: 107-116.

Rachmawati, F., A. Purwito, N. M. A. Wiendi, N. A. Mattjik and B. Winarto. 2014. In vitro mass propagation of Dendrobium 'Gradita 10' orchids via somatic embryogenesis. J. Hortic. 24(3): 196-209.

Rafique, R., B. Fatima, S. Mushtaq, M. Shahid Iqbal, M. Rasheed, M. Ali and S. Z. UI Hasan. 2012. Effect of indole-3-butyric acid (IBA) on in vitro root induction in Dendrobium orchid (Dendrobium sabin H.). Afr. J. of Biotechnol. 11(20): 4673-4675.

Rittirat, S., K. Thammasiri and S. Te-chato. 2012. Effect of media and sucrose concentrations with or without activated charcoal on the plantlet growth of Phalaenopsis cornucervi (Breda) Blume and Rchb. f. J. Agric. Technol. 8(6): 2075-2085.

Roy, J. and N. Banerjee. 2003. Induction of callus and plant regeneration from shoot-tip explants of Dendrobium fimbriatum Lindl. Var. oculatum Hk. F. Sci. Hortic. 97: 333-340.

Roy, J., S. Naha, M. Majumdar and N. Banerjee. 2007. Direct and callus-mediated protocorm-like body induction from shoot-tips of Dendrobium chrysotoxum Lindl. (Orchidaceae). Plant Cell Tissue Organ Cult. 90: 31-39.

Singh, B. 2014. Effect of desiccation and chilling treatment on somatic embryo development and germination in rough lemon (Citrus jambhiri Lush). Br. Biotechnol. J. 4(2): 136-148.

Srinivas, L., T. R. Ganapathi, P. Suprasanna and V. A. Bapat. 2006. Desiccation and ABA treatment improves conversion of somatic embryos to plantlets in banana (Musa spp.) cv. Rasthali (AAB). Indian J. Biotechnol. 5: 521-526.

Sujjaritthurakarn, P. and K. Kanchanapoom. 2011. Efficient direct protocorm-like bodies induction of dwarf Dendrobium using Thidiazuron. Notulae Sci. Biol. 3(4): 88-92.

The Indonesian Center for Plant Variety Protection. 2009. Orchid Descriptions of Dendrobium Indonesia Raya cv. Ina. Registration certificate of New Variety derived from Breeding Program. No: 161/PVHP/2009. Available from: http://www.setjen.deptan.go.id/ ppvt/. [Last accessed on 2009 Jun 22].

Vacin, E. F. and E. W. Went. 1949. Some pH changes in nutrient solution. Bot. Gaz. 110: 605-613.

Winarto, B. 2012. In vitro proliferation study of three Indonesian Dendrobium's protocorm-like bodies (PLBs) on different fertilizer media. In: Proceedings of National Orchid. Publisher Indonesian Center for Horticulture Research Development, p. $154-168$.

Winarto, B., F. Rachmawati, A. S. Setyawati and J. A. Teixeira da Silva. 2013. Mass propagation of Dendrobium 'Zahra FR 62': A new hybrid used for cut flowers, using bioreactor culture. Sci. Hortic. 161: 70-180.

Winarto, B. and F. Rachmawati. 2013. In vitro propagation protocol of Dendrobium 'Gradita 31' via protocorm like bodies. Thammasat Int. J. Sci. Technol. 18(2): 54-68.

Zhao, P., F. Wu, F. S. Feng and W. J. Wang. 2008. Protocorm-like body (PLBs) formation and plant regeneration from the callus culture of Dendrobium candidum Wall ex Lind. In Vitro Cell Dev. Biol. Plant. 44(3): 178-85. 